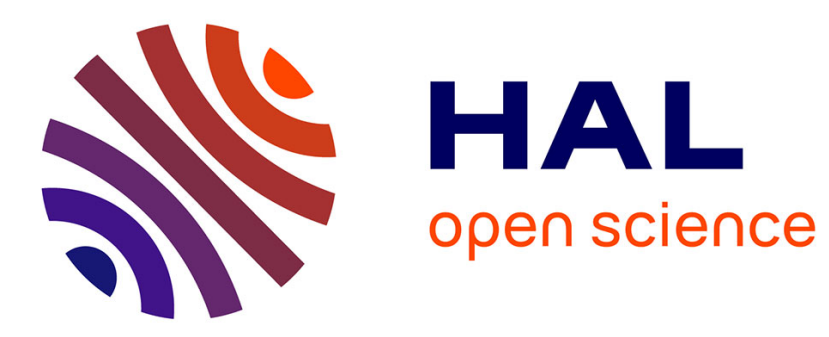

\title{
Terahertz Characterization of Roman Amphora Sherds
}

\author{
Min Zhai, A. Locquet, C. Carreras, K. Kazek, D.S. S Citrin
}

\section{To cite this version:}

Min Zhai, A. Locquet, C. Carreras, K. Kazek, D.S. S Citrin. Terahertz Characterization of Roman Amphora Sherds. IRMMW-THz (45th International Conference on Infrared, Millimeter, and Terahertz Waves), Nov 2020, Boulder (virtual), United States. hal-03085987

\section{HAL Id: hal-03085987 \\ https://hal.science/hal-03085987}

Submitted on 22 Dec 2020

HAL is a multi-disciplinary open access archive for the deposit and dissemination of scientific research documents, whether they are published or not. The documents may come from teaching and research institutions in France or abroad, or from public or private research centers.
L'archive ouverte pluridisciplinaire HAL, est destinée au dépôt et à la diffusion de documents scientifiques de niveau recherche, publiés ou non, émanant des établissements d'enseignement et de recherche français ou étrangers, des laboratoires publics ou privés. 


\title{
Terahertz Characterization of Roman Amphora Sherds
}

\author{
Min Zhai, ${ }^{1}$ Alexandre Locquet, ${ }^{1}$ C. Carreras Monfort, ${ }^{2}$ Kevin Alexandre Kazek, ${ }^{3}$ and D.S. Citrin ${ }^{1}$ \\ ${ }^{1}$ Georgia Tech-CNRS UMI-2958, Georgia Tech Lorraine, 2 Rue Marconi, 57070 Metz, France and School of \\ Electrical and Computer Engineering, Georgia Institute of Technology, Atlanta, Georgia 30332-0250 USA \\ ${ }^{2}$ Department de Ciències de l'Antiguitat I de l'Edat Mitjana, Universitat Atònoma de Barcelona, Edifici B \\ Facultata de Filosofia I Lletres, 08193 Bellaterra (Barcelona), Spain \\ ${ }^{3}$ Musée de la Cour d'Or-Metz Metropole, 2 Rue du Haut Poirier, 57000 Metz, France
}

\begin{abstract}
Amphorae frequently have a whitish skin that has been mistaken for a slip or painted layer over the otherwise pinkish ceramic. This skin is due to the simultaneous presence of calcite and $\mathrm{NaCl}$ in the clay, leading to depletion of red iron oxides near the surface. We demonstrate that terahertz time-of-flight tomography can provide a nondestructive, contactless means to measure the skin thickness on amphora sherds, finding a thickness of $\sim 50 \mu \mathrm{m}$.
\end{abstract}

\section{INTRODUCTION}

A mphorae were used in bulk-commodity long-distance trade in the Roman Empire. A whitish skin [1] is often present. We measure the skin thickness $w$ using terahertz (THz) time-of-flight (TOF) tomography. While [2-4] shows that the layer is a skin, surprisingly little is known quantitatively about its thickness on anything less than a mm scale [3].

The Baetican amphora sherds are shown in Fig. 1. A caliper measurement gives $w \sim 30-40 \mu \mathrm{m}$. Clearly, nondestructive and noncontact techniques providing quantitative $\mu \mathrm{m}$-scale resolution are called for.

\section{RESULTS}

THz TOF tomography experiments use a TeraView TPS Spectra 3000 . The optical delay $\Delta T$ between successive echoes is determined by $w$ and its refractive index $n$. The sherds were raster-scanned in the transverse $x$ and $y$ directions in $200 \mu \mathrm{m}$ steps over the regions of the exteriors. We establish the optical thickness $w_{\mathrm{opt}}=c \Delta T / 2$ where $c$ is the in vacuo speed of light. The actual thickness of the layer is $w=w_{\mathrm{opt}} / n$. To reconstruct the sample from our measurement, i.e., to recover the layer thickness $w$, we employ sparsity-based deconvolution (SD) $[24,25,26]$, which in some cases can beat the naïve axial resolution limit and reconstruct samples with thin layers. Taking $n \sim 2$ [5], we find $w \sim 50 \mu \mathrm{m}$.

B-scans based on such measurements are shown in Fig. 2. Cscans (not shown) enable us to acquire statistics for $w$.

\section{CONCLUSION}

We present nondestructive, noncontact measurements of skin thickness $w$ in Roman amphora sherds by means of THz TOF tomography for the first time providing quantitative stratigraphic characterization. We find $w$ to be $\sim 50 \mu \mathrm{m}$ with a $5-\mu \mathrm{m}$ standard deviation across the regions of the two sherds.

\section{REFERENCES}

[1] D.P.S. Peacock, 1984, "Seawater, Salt and Ceramics" in Fulford, M. G. and Peacock, D.P.S, 1984, "The Avenue de Président Habib Bourguiba, Salammbó: The pottery and ceramic objects from the site," in Excavations at Carthage, The British Museum, 1, 2, (Sheffield, 1984), 263-4. For a more recent study, see J. von der Crone and M. Maggetti, "Experimental firing of clays using salt water," in Archaeometry 98, Proceedings of the $31^{\text {st }}$ Symposium, Budapest, 26 April-3
May 1998, Vol. I, BAR International Series, eds. E. Jerem, K.T. Biro, and E. Rudner (Archaeopress - Archaeolingua, BAR, 2002)) Centr. Eur. Ser. 1.

[2] J. Benton, P. Grave, E.G.D. Robinson, and R.V.S. Wright, "Jericho tomb B47: A Palestinian Middle Bronze Age tomb in the Nicholson Museum," Mediterranean Archaeology vol. 5/6, pp. 59-110, 1993.

[3] J. Molera, T. Pradell, and M. Vendrell-Saz, "The colors of Ca-rich ceramic pastes: Origin and characterization," Appl. Clay Sci. vol. 13, pp. 187-202, 1998.

[4] B.L. Sherriff, C. McCammon, and L. Stirling, "A Mössbauer study of the color of Roman pottery from the Leptimnus archaeological site, Tunisia," Geoarchaeology vol. 17, pp. 863-74, 2002.

[4] E. Topsakai, T. Karacolak and E.C. Moreland, "Glucose dependent dielectric properties of blood plasma," XXXth URSI Symposium, pp. 1-4, Istanbul, Turkey, Aug. 13-20, 2011.

[5] J. Labaune, J.B. Jackson, K. Fukunaga, J. White, L. d'Alessandro, A. Whyte, M. Menu, and G. Mourou, "Investigation of terra cotta artefacts with terahertz,” Appl. Phys. A vol.105, pp. 5-9, 2011.
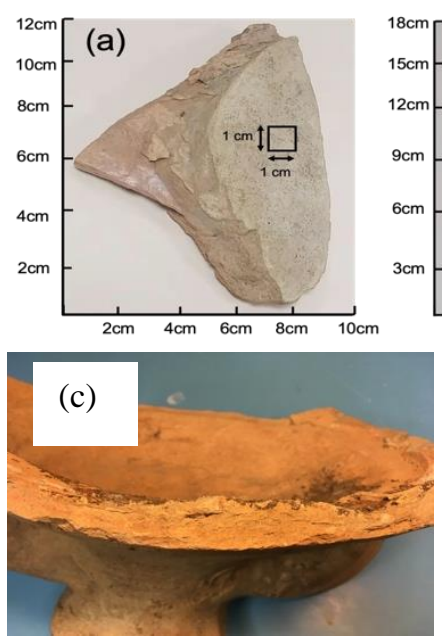
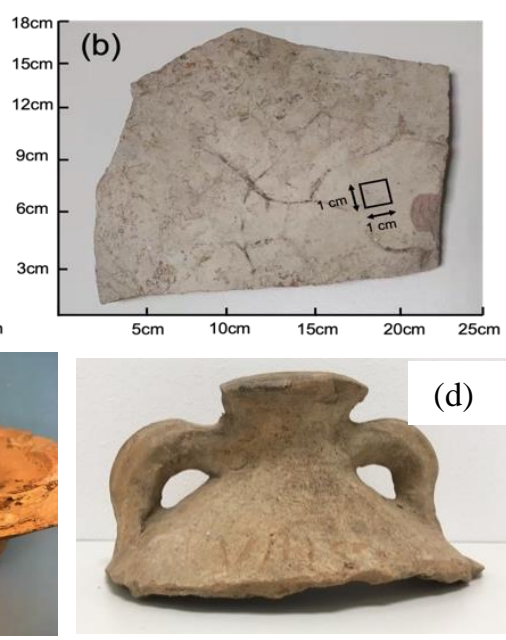

Fig. 1. Amphora sherds (a) 1 and (b) 2 . Black rectangles $\left(\sim 1 \times 1 \mathrm{~cm}^{2}\right)$ show areas studied. (c) shows sherd break exhibiting laminar fracture within the body fabric. (d) shows large fragment from same amphora from which the sherds nricinate $\Delta$ oraffito is ceen in $(d)$
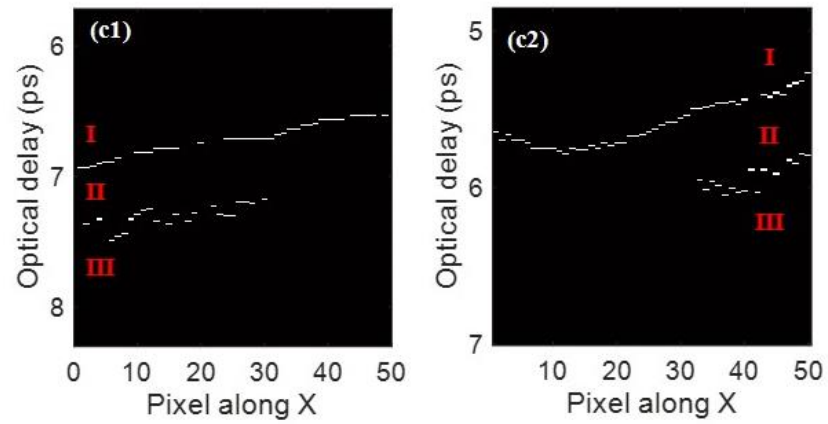

Fig. 2. (a) and (b) show binary B-scans with echo arrival time reconstructed by SD along cross section shown in regions in Fig. 1(a) and (b). 